\title{
Polyethylene glycol affects goats' feeding behavior in a tannin-rich environment
}

\author{
SERGE Y. LANDAU, AVI PEREVOLOTSKY, DORIT KABABYA, NISSIM SILANIKOVE, RONIT NITZAN, \\ HAGIT BARAM, AND FREDERICK D. PROVENZA
}

Authors Landau and Perevolotsky are Range Scientists, Nitzan is Agricultural Research Technician, and Baram is Computer Programmer, Department of Natural Resources, Institute of Field and Garden Crops, Agricultural Research Organization; The Volcani Center, P.O. Box 6, Bet Dagan 50250, Israel; Kababya is Field Advisor, Sheep and Goats Department, Extension Service, Ministry of Agriculture, P.O. Box 28, Bet Dagan 50250, Israel; Silanikove is Animal Scientist, Institute of Animal Science, Agricultural Research Organi-ation, The Volcani Center, P.O. Box 6, Bet Dagan 50250, Israel; Provenza is Professor, Department of Rangeland Resources, Utah State University, Logan, Utah, USA 84322-2810. Corresponding author: Dr. S. Landau; fax: 972 3 9669642;E-mail: vclandau@agri.gov.il

\section{Abstract}

High concentrations of condensed tannins in browse impair brush clearing by goats. We studied the effect of polyethylene glycol (PEG, MW 4000), a polymer that binds condensed tannins, on the feeding behavior of Damascus goats (Capra hircas) on a range dominated by tannin-rich lentisk (Pistacia lentiscus L.). This was done with or without a nutritious alternative to browse (alfalfa hay) available at pasture. In phase 1 , no hay was provided to goats; in phase 2 , hay was distributed daily in the field. In both phases, 6 goats had free access to PEG while at pasture, while 6 goats that grazed separately on another paddock did not. All goats received each night an allowance of concentrate $(400 \mathrm{~g}$ day $^{-1}$ of $40 \%$ ground corn grain, $40 \%$ ground barley, $17 \%$ soybean meal and $3 \%$ of a mineral-vitamin premix, and contained as fed $16 \%$ crude protein (CP) and $2.66 \mathrm{Mcal} \mathrm{kg}^{-1}$ of Metabolizable Energy). The 2 groups of goats alternated daily between paddocks. Goats supplemented with PEG spent more time browsing lentisk than goats in the control group (73 and $\mathbf{4 1 \%}$, respectively, $P<\mathbf{0 . 0 0 0 1 )}$. Goats in the control group spent more time foraging on dry grasses than their PEG-fed counterparts $(28$ and $12 \%$, respectively, $P<0.0001)$. Goats from the PEG group gained body weight at a higher rate than controls. The daily intake of PEG was $450 \mathrm{~g}$, with an intake rate of $1.2 \mathrm{~g}$ $\sec ^{-1}$. Supplemental alfalfa hay substituted partly for dry grasses in goats' diets, but did not modify the percent of time goats in either treatment spent browsing lentisk. Our data suggest that PEG has the potential to increase intake of tannin-rich species, even where alternative fodder of better nutritional quality is present. However, self-feeding of PEG may not be the best way to provide PEG because goats may ingest more PEG than needed to annul the aversive effects of tannins on food intake.

Key Words: Mediterranean browse; self-regulation; nutrition

Efforts are underway to use goats (Capra hircas) to reduce the abundance of brush in Mediterranean ecosystems where brush

Contribution from the Agricultural Research Organization, Institute of Field and Garden Crops, Bet Dagan, Israel, No. 148/2000. This research was supported by Research Grant No. US-2625-95 from BARD, The United States-Israel Binational Agricultural Research and Development Fund.

Manuscript accepted 21 Mar. 02.

\section{Resumen}

Las altas concentraciones de taninos condensados en el forraje ramoneable de los arbustos impide el control de ellos mediante el uso de caprinos. Estudiamos el efecto del polietilen glicol (PEG, MW 4000), un polímero que une a los taninos condensados, en el comportamiento alimenticio de cabras (Capra hircas) de Damasco en un pastizal dominado por "Lentisk" (Pistacia lentiscus L.), una especie rica en taninos. Esto fue hecho con y sin una alternativa nutritiva (heno de alfalfa) disponible para ramonear en el potrero. En la fase 1 no se suministró heno a las cabras; en la fase 2, el heno se distribuyó diariamente en el campo. En ambas fases, 6 cabras tenían libre acceso al PEG mientras estaban el potrero, en tanto que otras 6 cabras que apacentaban separadamente en otro potrero no tuvieron acceso al PEG. Todas las cabras recibieron cada noche una ración de concentrado $(400 \mathrm{~g}$ día-1, $40 \%$ de grano de maíz molido, $40 \%$ de cebada molida, $17 \%$ de harina de soya y $3 \%$ de una mezcla de vitaminas y minerales, este concentrado tenia un $16 \%$ de proteína cruda y 2.66 Mcal $\mathrm{kg}^{-1}$ de energía metaboizable). Los 2 grupos de cabras se alternaron diariamente entre los potreros. Las cabras suplementadas con PEG pasaron mas tiempo ramoneando el "Lentisk" que las cabras del grupo control ( 73 y $41 \%$, respectivamente, $P<$ 0.0001). Las cabras del grupo control pasaron más tiempo apacentando zacates secos que las cabras suplementadas con PEG (28 y $12 \%$ respectivamente, $P<0.0001)$. Las cabras del grupo con PEG ganaron peso a una mayor tasa que las del grupo control. El consumo diario de PEG fue de $450 \mathrm{~g}$ con una tasa de ingestión de $1.2 \mathrm{~g}$ seg-1. La alfalfa suplementada substituyó parcialmente los zacates secos de la dieta de las cabras, pero no modificó el porcentaje de tiempo que las cabras de cualquier grupo pasaron ramoneando el "Lentisk" Nuestros datos sugieren que el PEG tiene potencial para incrementar el consumo de especies ricas en taninos, aun donde un alimento alternativo de mejor calidad nutricional este presente. Sin embargo, el autoconsumo de PEG puede no ser la mejor manera de suministrarlo porque las cabras pueden ingerir mas PEG del requerido para anular el efecto aversivo de los taninos en el consumo de alimento.

encroachment increases the danger of fire (Perevolotsky and Seligman 1998) and limits recreational value. However, high concentrations of tannin in some species of Mediterranean browse impair browsing. Supplementation with Polyethylene Glycol (PEG), an inert polymer that can bind tannins irreversibly 
(Jones and Mangan 1977), alleviates the aversive effects of tannins on feed intake (Silanikove et al. 1996, 1997).

Given a choice between blackbrush (Coleogyne ramosissima Torr.) twigs of different tannin content, PEG-supplemented goats consumed more than unsupplemented goats of the tannin-rich younger twigs, which are more nutritious than the older-growth alternative (Titus et al. 2001). In most farm situations in the Mediterranean area, goats eat numerous feeds differing widely in nutritional quality and tannin content (Kababya et al. 1998). Titus et al. (2000) proposed that tannin neutralization by PEG should lead to an increased intake of tannin-rich browse, provided that the alternative fodder is poorer in nutrients, but did not consider a tannin-free, nutritious alternative. Alfalfa hay is an excellent tannin-free fodder (Broderick and Albrecht 1997) that can be used as sole food for non-productive goats (Morand-Fehr et al. 1991). Goats eat more tannin-free legume hay than tannin-containing browse when offered tannin-free legume hay or tannincontaining browse as a sole food (Perevolotsky et al. 1993). Therefore, given a choice between tannin-free hay and tannin-containing browse, goats may feed mostly on the more nutritious hay, independent of PEG availability.

The different methods proposed for PEG administration involve giving a predetermined dose of PEG (Landau et al. 2000). However, when dietary tannins exert post-ingestive malaise, the best estimator of the effective dose may be the animal itself (Provenza 1996). Lambs fed concentrates differing in concentrations of quebracho tannin showed a close relationship between dietary tannin content and voluntary intake of PEG (Provenza et al. 2000). Self-feeding would be the most convenient way to provide PEG to ranging goats, but it has never been implemented under farm conditions.

The present study evaluated the amount of $P E G$ consumed by goats foraging in a tannin-rich Mediterranean environment, and assessed the change in feeding behavior when alfalfa hay was available as a supplement.

\section{Methods}

\section{Animals}

Twelve multiparous Damascus goats were allotted to 2 treatments (PEG and C, "control") after weaning of their kids on 2 August 1999. Average body weights were equalized between the PEG and $\mathrm{C}$ groups (53.1 and $53.4 \mathrm{~kg}, \mathrm{SE}=3.7$, respectively). Body condition scores were 3.04 and 2.91 at the sternal and lumbar sites, respectively (Santucci et al. 1991). Goats were accustomed to grazing on a Mediterranean shrubland, but had been housed for 3 months before the experiment and fed on alfalfa hay and a commercial concentrate (16\% of crude protein, Ambar, Hadera, Israel). Goats were identified using colored plastic bracelets inserted on 2 legs.

\section{Study site}

The experiment took place in August in the Sharon Park $\left(32^{\circ} 25^{\prime} \mathrm{N}, 34^{\circ} 52^{\prime} \mathrm{E}\right)$, a coastal sand plain located about $30 \mathrm{~km}$ North of Tel Aviv, in Central Israel. The area is dominated by lentisk shrubs (Pistacia lentiscus L.) and carob trees (Ceratonia siliqua L.), featuring 2-3 m high coppice round islets. Isolated bushes of Ephedra foemina Forskk., Retama rateam Forskk. and Thymelea hirsuta L., xerophytes originating from the desert, were also common in the area. Limited amounts of dry annual herbaceous vegetation, including Carthamus nitidus Boiss., Foeniculum vulgare Miller, Rubia tenuifolia Dum., and annual grasses, occurred on the range. An area of 0.215 ha was divided into 2 paddocks (Fig. 1) of $950 \mathrm{~m}^{2}$ (termed $(\mathrm{SE}=0.25)$ and 2.46 and $2.41(\mathrm{SE}=0.33)$

the "Ephedra" paddock) and 1,200 $\mathrm{m}^{2}$ (termed the "Carob" paddock), using a 5wire electric fence (RY2 model, $14000 \mathrm{~V}$, Reuven Yoffe Ltd., Kfar Gidon, Israel).

\section{Animal management}

Due to high summer temperatures, goats grazed from 0600 to 1000 hours and from 1600 to 1930 hours. No water was available at pasture. Goats were corralled and watered under the shade of a carob tree from 1000 to 1600 hours and from 1930 to 0600 hours. At night, they rested as 1 group and they were group-fed $400 \mathrm{~g}$ head $^{-1}$ of a commercial concentrate. The concentrate (Ambar, Hadera, Israel) consisted of $40 \%$ ground corn grain, $40 \%$ ground barley, $17 \%$ soybean meal and $3 \%$ of a mineral-vitamin premix, and contained, as fed, $16 \%$ crude protein (CP) and $2.66 \mathrm{Mcal} \mathrm{kg}^{-1}$ of Metabolizable Energy. Goats from the 2 treatments grazed separately, alternating paddocks each day, to reduce pasture bias. The experiment ran for 3 to 23 August 1999. Flakes of PEG (Molecular Weight 4000) were available ad libitum for the PEG group.

Phase 1: The objective of this phase was to investigate the effect of PEG on feeding behavior when alfalfa hay was not available at pasture. No supplement, apart from PEG, was offered at pasture from day 1 to day 15 . Goats were weighed on days 0 and
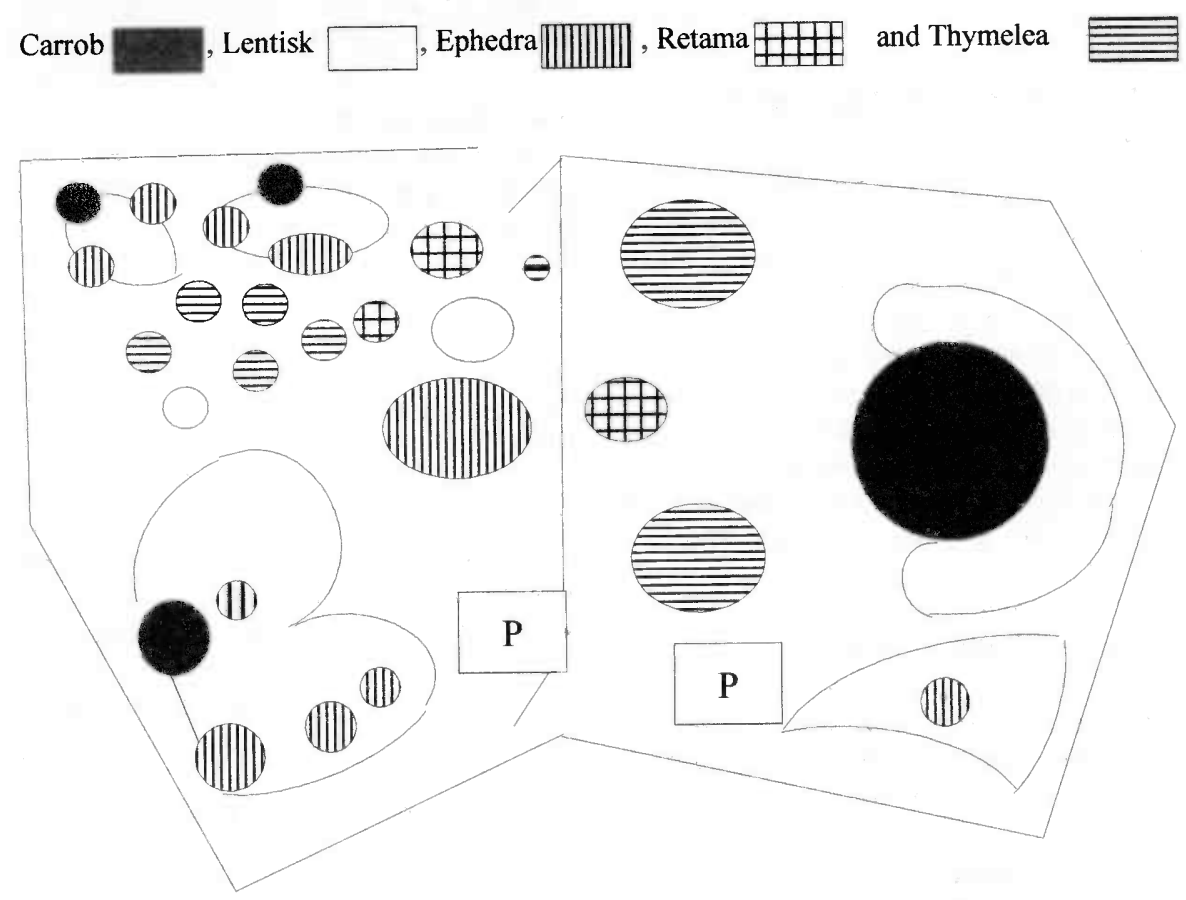

Fig. 1. Grazing paddocks "Carob" (right) and "Ephedra" (left), showing the location of carob trees, and lentisk, Ephedra, Retama, and Thymelea bushes. The location of the PEG trough is indicated by the $P$ box. 
14 (to $\pm 10 \mathrm{~g}$ ) to evaluate body weight changes.

Phase 2: From days 16 to 20 , goats in both groups were offered at pasture the same excellent quality alfalfa hay - containing, on DM basis, $19 \% \mathrm{CP}, 57 \%$ neutral detergent fiber (NDF), and $33 \%$ acid detergent fiber (ADF) - that was used before the experiment. On those days, intact and partly defoliated lentisk twigs contained, on DM basis: 8.1 and $6.7 \%$ of CP, 41 and $65 \%$ of NDF, and 29 and $44 \%$ of ADF, respectively. Lentisk leaves contained $22 \%$ condensed tannins. It was expected that goats would consume most of their diet from hay, rather than the hightannin foods.

\section{Behavior scanning}

The behavior of each goat was recorded by 2 observers every 5 minutes during the morning and evening grazing sessions for 14 days of phase 1 , and during 5 days of phase 2, using the scan sampling method (Altmann 1974). Behavior categories were standing, lying (including ruminating, that could not be clearly discerned), playing, eating, searching at a foraging site, consuming PEG (days 1-20) and consuming hay (days 16-20). Within the eating category, some plants were identified to species i.e., carob, lentisk, E. foemina, $R$. rateam and $T$. hirsuta, whereas dry herbs were grouped. No details concerning consumed part plants (fruit, leaves, and stems) were recorded.

\section{Individual PEG and hay intake}

Polyethylene Glycol (PEG) was provided in a trough placed on a digital scale (Merav 2002, Shekel Scales Ltd., Rosh Haain, Israel), and was available at all times to the PEG group. Hay was provided ad libitum on a similar scale on days 16-20. The scales were fenced to restrict access to only 1 animal at a time. Software included an algorithm devised to weigh objects up to $100 \mathrm{~kg}$ with an accuracy of \pm $10 \mathrm{~g}$. Weighing occurred automatically 30 times/second and digits were displayed when the SE of weight values reached \pm $10 \mathrm{~g}$, i.e., the accuracy of the scale. Every time a goat initiated or ended feeding on PEG or hay, time and scale display were recorded by an observer. This allowed us to calculate the individual eating rate of PEG and hay for each goat.

\section{Total feed intake}

Total feed intake was assessed on days 14 and 15 (phase 1) using a modification of the method developed by Penning and Hooper (1985). Intake of forage was deter-

Table 1. Initial body weight, daily body weight changes (days 1-14), duration of grazing session and the intake of fresh matter (FM) at pasture (days 14-15) in Damascus goats feeding on a Mediterranean shrubland dominated by lentisk and carrob and self-supplemented (PEG) or not (C) with PEG ad libitum (first phase of experiment).

\begin{tabular}{llll}
\hline \hline & $\mathrm{C}$ & PEG & SEM \\
\hline Initial body wt. $(\mathrm{kg})$ & 53.4 & 53.1 & 3.7 \\
Daily body wt. change $(\mathrm{kg})^{1}$ & $-0.109 \mathrm{a}$ & $-0.003 \mathrm{~b}$ & 0.028 \\
& & & \\
Fresh matter intake $(\mathrm{kg})^{1}$ & & & 0.27 \\
Including PEG & $0.91 \mathrm{~b}$ & $2.11 \mathrm{a}$ & 0.24 \\
Not including PEG & 0.91 & 1.58 & \\
\hline
\end{tabular}

${ }^{1}$ Within rows means significantly different at $\mathrm{P}<0.05$ have different letters.

mined by the difference in body weight before and after a grazing session, corrected for respiration evaporation losses (insensible weight loss). The method requires that excreta are collected and remain on the animals. To do so, goats were fit with harnesses in which feces and urine were collected on disposable paper diapers. Goats were weighed $( \pm 10 \mathrm{~g})$ before and after grazing sessions of 3 hours. Insensible weight loss per unit of time was calculated for each goat before and after the morning and afternoon grazing sessions in fasting sessions of 30 to 40 minutes. The 12 treatment goats were muzzled as they followed 2 unmuzzled goats while they grazed. Treatment goats were weighed before and after each mock grazing session and insensible weight loss was calculated. Intake was corrected for each grazing session using insensible weight loss per unit of time during the session multiplied by the duration of session.

\section{Statistical analyses}

Changes in body weight (BW) and average daily gain were compared between groups by analysis of variance (GLM of SAS 1989) with treatment (PEG or C) as main effect. Feed intake (days 14 and 15) was compared between groups, using a model that included treatment (PEG or C), day (confounded with paddock), and their interaction.

The effect of paddock on the individual intake of PEG (PEG group only) was established using a repeated measurement procedure. The partition of behaviors (in $\%$ of total activities) was calculated for each day, separately for the morning and afternoon grazing sessions, and variances were homogenized by arcsine (square root) transformation.

The repeated measures analyses of variance for the different behavioral categories during phase 1 were carried out on the transformed data, using a model with paddock ("Carob" or "Ephedra"), treatment (PEG or C), and grazing session (morning and afternoon) as main effects, along with their interactions.

The effect of feeding hay (phase 2) on the different behavioral categories, using pooled data from morning and afternoon sessions, was carried out using a model with paddock ("Carob" or "Ephedra"), treatment (PEG or C), and hay (yes or no), as main effects, along with their interactions (GLM of SAS 1989). Goats nested within treatments (PEG or C) was the error term and day was the repeated measure.

Pearson correlation (SAS 1989) was run to assess the relationship between individual values for percent of time spent browsing lentisk and PEG intake.

\section{Results}

\section{Phase 1: no hay supplementation at pasture Effects of PEG on body weight changes and feed intake at pasture}

From days 0 to 14 , unsupplemented goats lost $109 \mathrm{~g}$ day $^{-1}$, whereas their PEGfed counterparts nearly maintained body weight (Table $1, \mathrm{P}=0.02$ ).

On days when pasture intake was assessed (days 14 and 15), goats grazed $5.1(\mathrm{SE}=0.12)$ hours and $6.2(\mathrm{SE}=0.25)$ hours. The total intake at pasture (including $\mathrm{PEG})$ was higher $(\mathrm{P}<0.05)$ for $\mathrm{PEG}$ than $\mathrm{C}$ animals on both days (Table 1). When the intake of PEG was subtracted from the total intake, the average intake at pasture was still more than $50 \%$ greater in PEG-treated animals, but the difference was not significant $(P=0.10)$ due to small sample sizes and high variability.

\section{Individual PEG intake}

Throughout the experiment, intake of PEG by individual goats ranged from 254 to $733 \mathrm{~g} \mathrm{day}^{-1}$ with an average of $456 \mathrm{~g}$ $\operatorname{day}^{-1}(\mathrm{SE}=44)$, and did not differ between the carob and "Ephedra" paddocks. There was a small but steady logarithmic increase in PEG intake throughout the 
Table 2. Percentages of behaviors recorded in Damascus goats feeding on a Mediterranean shrubland dominated by lentisk and carob and self-supplemented with PEG ad libitum on days when hay was provided ad libitum at pasture. Statistical analyses refer to arcsine (square root) transformed data.

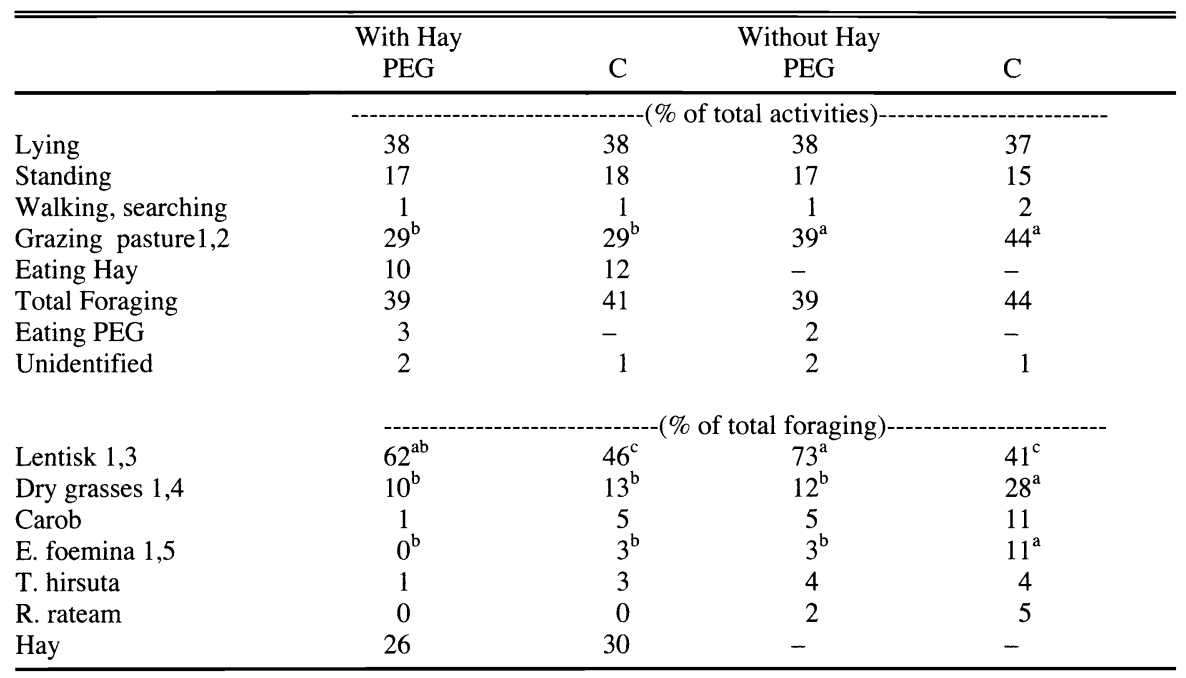

${ }_{2}^{1}$ Within rows means significantly different at $\mathrm{P}<0.05$ have different letters

2 The only significant effect in the model was hay, $\mathrm{P}<0.01$.
${ }_{4}$ The only significant effect in the model was treatment, $\mathrm{P}<0.001$

${ }_{5}^{4}$ Significant effects in the model were treatment, $\mathrm{P}<0.0001$, hay, $\mathrm{P}<0.05$ and treatment $\mathrm{x}$ hay, $\mathrm{P}<0.05$.

${ }^{5}$ Significant effects in the model were treatment, $\mathrm{P}<0.01$ and hay, $\mathrm{P}<0.01$.

experiment in spite of the high variation (SE ranged from 35 to $85 \mathrm{~g} \mathrm{day}^{-1}$ ).

The number of foraging visits to $\mathrm{PEG} /$ day was $8.43(\mathrm{SE}=0.77$ ) (range 1 to $27)$, with an average intake rate of $1.20 \pm$ $0.03 \mathrm{~g} \mathrm{sec}^{-1}$ (range 0.25 to 2.23 ).

\section{Effects of PEG and paddock on feed- ing behavior}

Overall, grazing represented more than $40 \%$ of all activities. Eating lentisk was the most frequent foraging activity, and represented a greater share of grazing in PEG than C goats (73\% and $41 \%$, respectively $\mathrm{P}<0.001$; Table 2 ). In contrast, $\mathrm{C}$ goats allocated more time than their PEG counterparts to foraging on dry grasses (28\% and $12 \%, \mathrm{P}<0.0001)$. Paddock did not affect the response. Goats spent more time lying in the morning than in the afternoon, and there was no effect of paddock or treatment (not shown).

The time spent foraging on carob or $E$. foemina foliage was affected $(\mathrm{P}<0.0001)$ by their abundance on the paddocks. Goats in both groups spent more time browsing carob in the Carob than in the "Ephedra" paddock ( $16 \%$ and $1.4 \%$, respectively). In addition, a strong $(\mathrm{P}<0.0001)$ treatment $\mathrm{x}$ paddock effect was noted: Control goats spent more time than PEG goats feeding on carob while grazing in the carob paddock, and more time foraging on $E$. foemi$n a$ while on the "Ephedra" paddock.

\section{Phase 2: hay supplementation at pasture}

There was no interaction between " paddock" and "hay" across days on goats behavior. Thus, the subsequent analyses included the effects of treatment (PEG), hay, and their interaction on behavioral features averaged across paddocks (Table 2).

Feeding hay reduced grazing activity $(\mathrm{P}$ $<0.01$ ), but did not affect total foraging activity (including foraging on hay). Haysupplementation reduced foraging on dry grasses $(\mathrm{P}<0.05)$ and $E$. foemina $(\mathrm{P}<$ 0.01 ) in group $C$, but not in group PEG. Providing hay did not modify the time spent browsing lentisk in either group. Thus, goats did not substitute hay for tannin-rich lentisk.

The daily intake of hay did not differ between PEG and C (276 and $248 \mathrm{~g} \mathrm{day}^{-1}$ ). Nor did frequency of visits to hay differ between groups. All goats spent approximately 40 minutes/day foraging on hay, but rate of intake was low $\left(0.110 \mathrm{~g} \mathrm{sec}^{-1}\right)$, and was not affected by PEG.

Supplemental hay did not modify PEG intake: values for intake, number of visits, and rate of intake were $425(\mathrm{SE}=48) \mathrm{g}$ day $^{-1}, 8.40(\mathrm{SE}=0.93)$, and $1.20(\mathrm{SE}=$ $0.04) \mathrm{g} \mathrm{sec}^{-1}$, respectively.

\section{Phases 1 and 2: Self-regulation of PEG intake}

There was no correlation $(\mathrm{R}=0.08, \mathrm{P}=$ 0.40 ) between the individual frequencies ( $\mathrm{n}$ $=108$ ) of browsing lentisk and the amount of PEG consumed during a grazing session. This suggests that there was no causal relationship between the intake of tanninrich browse and that of PEG. Including all browse species slightly improved the relationship ( $\mathrm{R}=0.19, \mathrm{P}=0.04)$, but not enough for predictive purposes.

\section{Discussion}

Even though the intake of PEG by goats was high (456 g day ${ }^{-1}$, Fig. 2), it had no “ bulk" effect, and did not impair intake at pasture (Table 1). The PEG did not modify the share of time (as percent of total activities) spent foraging in either haysupplemented or non-supplemented goats (Table 2).

When the intake of PEG was subtracted from the total intake, the average intake at pasture was still more than $50 \%$ greater in PEG-treated animals, but the difference was not highly significant $(\mathrm{P}=0.10)$ due to small sample sizes and high variability. A limited effect of PEG on total intake at pasture was noted in some studies (Decandia et al. 2000), whereas others working with penned animals restricted in the variety of foods reported increased dry matter (DM) intake (Silanikove et al. 1996, Ben Salem et al. 2000, Titus et al. 2001). The availability of energy may have been affected by PEG, as evidenced by higher body gain during phase 1 of the present study (Table 1). This is consistent with results that PEG has the potential to increase productivity in goats feeding in tannin-rich Mediterranean environments (Gilboa et al. 2000, Decandia et al. (2000).

The high percentage of lentisk browsing by goats reflects the high frequency of lentisk on the range (Perevolotsky et al. 1998, Kababya et al. 1998). Control goats spent about $40 \%$ of their foraging time browsing lentisk, and their PEG-supplemented counterparts spent more than $70 \%$ of their foraging time browsing lentisk (Table 2). This is consistent with findings for caged goats fed lentisk twigs as the sole diet (Silanikove et al. 1996). Thus, PEG increased intake of lentisk, in accord with Decandia et al. (2000), and this has implications for improving the effectiveness of goats to prevent encroachment of lentisk in Mediterranean environments.

Surveys of chemical composition of Mediterranean species of browse in Israel and Italy show that lentisk is the richest in condensed tannins (Landau et al. 2000). In the present study, control and PEG-supplemented goats consumed 0.91 and 1.58 $\mathrm{kg}$ of fresh matter at pasture, respectively 


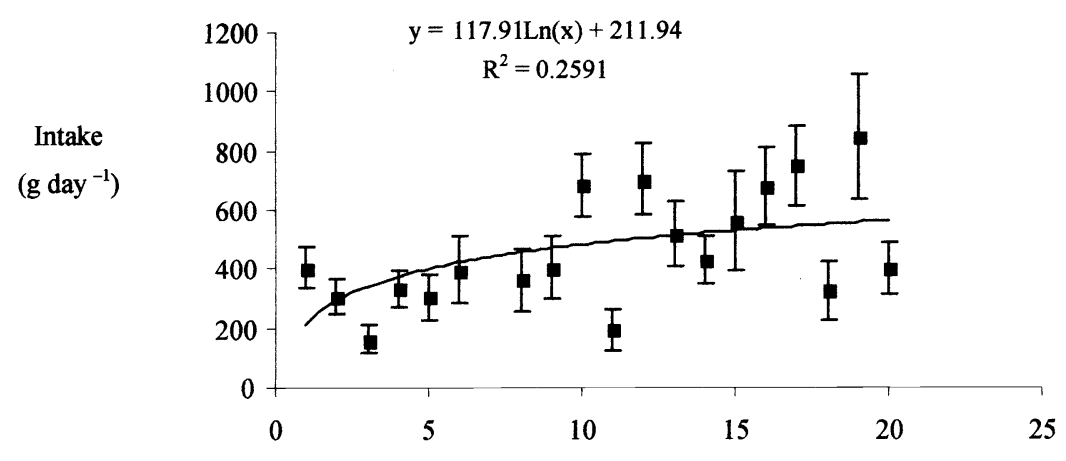

Days on experiment

Fig. 2. Individual intake of PEG $\left(\mathrm{g} \mathrm{day}^{-1}\right)$ throughout the experiment: means and SE.

(Table 1). In a previous study, with goats fed lentisk leaves solely, DM intake was increased from 460 to ca. $800 \mathrm{~g} \mathrm{day}^{-1}$ when PEG was provided at $20 \mathrm{~g} \mathrm{day}^{-1}$ (Silanikove et al. 1996). No further response in intake was noted when higher doses - 30 or $40 \mathrm{~g} \mathrm{day}^{-1}$ of PEG were administered. Goats in the PEG group of the present study ingested $456 \mathrm{~g}_{\text {day }}{ }^{-1}$ PEG on average. Thus, they ingested an amount of lentisk that did not exceed 2-fold that ingested by goats in the study by Silanikove et al. (1996), but they consumed an amount of PEG 10- to 20-fold higher. Thus it can be inferred that intake of PEG in our study was more than needed to maximize the intake of lentisk. Furthermore, the low correlation coefficient found between time spent browsing lentisk and the intake of PEG suggests goats did not self regulate intake of PEG based upon the amount of lentisk consumed. Though one must be cautious when comparing the effects of tannins from different sources (Clausen et al. 1991), a similar result occurred when sheep fed Acacia cyanophylla foliage had free access to PEG-containing feed blocks (Ben Salem et al. 2000).

The apparent "overeating" of PEG may be due in part to the aversive effects of tannins on the absorption of nutrients. Low levels of PEG allow DM intake to increase (Silanikove et al. 1996), but higher levels of PEG continue to increase digestibility of crude protein (CP) (Silanikove et al. 1996, Decandia et al. 2000). The high intake of PEG can then be interpreted as a way to maximize the availability of $\mathrm{CP}$, the first limiting factor for goats feeding on Mediterranean browse (Kababya et al. 1998).

Alfalfa hay is excellent fodder and can be used as sole food for non-productive goats (Morand-Fehr et al. 1991). All goats were familiar with alfalfa hay, so one might expect that they would feed mostly on hay, thus cutting the energy expenditure to search for high-tannin shrubs of mediocre nutritional value. In particular, it was anticipated that control goats, not provided with PEG, would switch to hay to a greater extent than PEG-supplemented counterparts. This did not happen. The low preference for alfalfa hay may have been due in part to the nightly allowance of $400 \mathrm{~g} /$ goat of concentrate high in crude protein $(16 \%)$.

Providing tannin-free alfalfa hay ad libitum at pasture reduced the time spent grazing by goats but did not alter their preference for lentisk (Table 2). Even the control goats ate only about $250 \mathrm{~g} \mathrm{DM}$ of hay and continued to browse. Hay replaced dry grasses and part of the carob and E. foemina in the diets, showing again that these species are not considered aversive by goats. This feeding behavior of goats is consistent with previous studies that show goats eat a variety of foods on heterogeneous Mediterranean pastures (Kababya et al. 1998). Interactions between a food's flavor, its nutrient and toxin concentrations and an animal's current nutritional state are likely to cause animals to eat a variety of foods (Provenza 1996). Two consequences of such strategy relevant to the present experiment are that all major species are sampled every day (Meuret 1997), and that the dietary concentration of condensed tannins is kept in a narrow range (Kababya et al. 1998). Therefore, browsing is never discontinued, even when more nutritious feeds are offered. This is in contrast with findings in sheep supplemented with PEG that avoided foods high in quebracho tannins when low-tannin alternatives were available
(Titus et al. 2000). Our data suggest that PEG will increase browsing of tannin-rich foliage even when alternative fodder of better nutritional quality is present, and that hay supplementation in periods of fluctuating pasture quality, a common practice in Mediterranean areas, is not incompatible with brush clearing by goats in general, and by PEG-supplemented goats, in particular.

\section{Conclusions}

Making PEG available free choice to goats feeding on tannin-rich Mediterranean shrubland resulted in improved body gain. Goats self-supplemented with PEG spend more time browsing tanninrich species, and less time ingesting species lower in tannins. However, goats may consume amounts of PEG higher than needed to counteract the aversive effects of tannins on DM intake. Feeding hay at pasture does not disrupt browsing activity of unsupplemented goats or of PEG-selfsupplemented goats.

\section{Literature Cited}

Altmann, J. 1974. Observational study of behavior: sampling methods. Behav. 49: 227-267.

Ben Salem, H., A. Nefzaoui, L. Ben Salem, and J.L. Tisserand. 2000. Deactivation of condensed tannins in Acacia cyanophylla Lindl. foliage by polyethylene glycol in feed blocks. Effect on feed intake, diet digestibility, nitrogen balance, microbial synthesis and growth by sheep. Livestock Prod. Sci. 64: 51-60.

Broderick, G.A. and K.A. Albrecht. 1997. Ruminal in vitro degradation of protein in tannin-free and tannin-containing forage legume species. Crop Sci. 37: 1884-1891.

Clausen, T.P., F.D. Provenza, E.A. Burritt, P.B. Reichardt, and J.P Bryant. 1991. Ecological implications of condensed tannin structure: a case study. J. Chem. Ecol. 16: 2381-2392.

Decandia, M., M. Sitzia, A. Cabiddu, D. Kababya, and G. Molle. 2000. The use of polyethylene glycol to reduce the anti-nutritional effects of tannins in goats fed woody species. Small Ruminant Res. 38:157-164.

Gilboa, N., A. Perevolotsky, S. Landau, and Z. Nitsan, Z. 2000. Increasing productivity in goats grazing mediterranean woodland and scrubland by supplementation of polyethylene glycol. Small Ruminant Res. 38:183-190.

Jones, W.T. and J.L. Mangan. 1977. Complexes of the condensed tannins of Sainfoin (Onobrychis viciifolia Scop.) with Fractions 1 Leaf protein and with submaxillary mucoprotein and their reversal by PEG and pH. J. Sci. Food Agr. 28:126-136. 
Kababya, D., A. Perevolotsky, I. Bruckental, and S. Landau. 1998. Selection of diets by dual-purpose Mamber goats in Mediterranean woodland. J. Agr. Sci., Camb. 131:221-228.

Landau, S., A. Perevolotsky, D. Bonfil, D. Barkai, and N. Silanikove. 2000. Utilization of low-quality resources by small ruminants in Mediterranean agro-pastoral systems: the case of browse and aftermath cereal stubble. Livestock Prod. Sci. 64: 39-49.

Meuret, M. 1997. Pre'hensibilite' des aliments chez les petits ruminants sur parcours en landes et sous-bois (in French, with English summary). INRA Prod. Anim., 10:391-401.

Morand-Fehr, P., E. Owen, and S. GigerReverdin. 1991. Feeding behaviour of goats at the trough, p. 3-12. In: P. Morand-Fehr (ed.), Goat Nutrition. Centre for Agr. Pub. Doc. (Pudoc), Wageningen, Netherlands.

Penning, P.D. and G.E. Hooper. 1985. An evaluation of the use of short-term weight changes in grazing sheep for estimating herbage intake. Grass and Forage Sci. 40: 79-84.

Perevolotsky, A. and N.G. Seligman. 1998. Role of grazing in Mediterranean rangeland ecosystems. BioSci. 48: 1007-1017
Perevolotsky, A., S. Landau, D. Kababya, and E.D. Ungar. 1998. Diet selection in dairy goats grazing woody Mediterranean rangeland. Appl. Anim. Behav. Sci. 57, 117-131

Perevolotsky, A., A. Brosh, O. Ehrlich, M. Gutman, Z. Henkin, and Z. Holzer. 1993. Nutritional value of common oak (Quercus calliprinos) browse as fodder for goats: experimental results in ecological perspective. Small Rumin. Res. 11:95-106.

Provenza, F. D. 1996. Acquired aversions as the basis for varied diets of ruminants foraging on rangelands. J. Anim. Sci. 74:2010-2020.

Provenza, F.D., E. A. Burrit, A. Perevolotsky, and N. Silanikove. 2000. Self-regulation of intake of Polyethylene Glycol by sheep fed diets varying in tannin concentration. J. Anim. Sci. 78:1206-1212.

SAS 1989. SAS/STAT Guide. Release 6.12. SAS Inst. Cary, N.C.

Santucci, P.M., A. Branca, M. Napoleone, R. Bouche, G. Aumont, F. Poisot, and G. Alexandre. 1991. Body condition scoring in goats in extensive conditions. In: P. MorandFehr (Ed.), Goat Nutrition, Pudoc, Wageningen, pp. 241-255.
Silanikove, N., N. Gilboa, and Z. Nitsan. 1997. Interactions among tannins, supplementation and polyethylene glycol in goats given oak leaves: effects on digestion and food intake. Anim. Sci. 64: 479-483.

Silanikove, N., N. Gilboa, I. Nir, A. Perevolotsky, and Z. Nitsan. 1996. Effect of a daily supplementation of polyethyleneglycol on intake and digestion of tannin-containing leaves (Quercus calliprinos, Pistacia lentiscus and Ceratonia siliqua) by goats. J. Agr. Food Chem. 44:199-205.

Titus, C.H., F.D. Provenza, A. Perevolotsky, and N. Silanikove. 2000. Preferences for foods varying in macronutrients and tannins by lambs supplemented with polyethylene glycol. J. Anim. Sci. 78:1443-01449.

Titus, C.H., F.D. Provenza, A. Perevolotsky, N. Silanikove, and J. Rogosic. 2001. Supplemental polyethylene glycol influences preferences of goat browsing blackbrush. J. Range Manage. 54:161-165. 